Sección Básica / Basic

Nota científica / Scientific note

\title{
Description of teratologies in two species of the genus Phyllophaga (Coleoptera: Scarabaeidae: Melolonthinae)
}

\author{
Descripción de teratologías en dos especies del género Phyllophaga \\ (Coleoptera: Scarabaeidae: Melolonthinae) \\ HÉCTOR MIGUEL GUZMÁN-VÁSQUEZ'; JULIÁN HERNÁNDEZ-CRUZ²; \\ HÉCTOR JAIME GASCA-ÁLVAREZ ${ }^{3}$
}

\begin{abstract}
${ }^{1}$ M. Sc. Instituto Politécnico Nacional, CIIDIR Unidad Oaxaca, Hornos 1003, Col Nochebuena, Santa Cruz Xoxocotlán, Oaxaca, México, hemigv85@gmail. com, https://orcid.org/0000-0003-0428-9983. ${ }^{2} \mathrm{Ph}$. D. Universidad Tecnológica de la Sierra Sur de Oaxaca, Magnolia s/n, Villa Sola de Vega, Oaxaca, México, jhcciidir@yahoo.com.mx, https://orcid.org/0000-0003-1365-5658. ${ }^{3} \mathrm{Ph}$. D. Programa de Investigación, Corporación Sentido Natural, Bogotá, Colombia, scarab7@gmail.com, https://orcid.org/0000-0002-0070-0715.
\end{abstract}

Corresponding author: Héctor Miguel GuzmánVásquez. M. Sc. Instituto Politécnico Nacional. CIIDIR Unidad Oaxaca. Hornos 1003. Col Nochebuena, Santa Cruz Xoxocotlán, Oaxaca, México,hemigv85@gmail.com, https://orcid. org/0000-0003-0428-9983.

Suggested citation:

GUZMÁN-VÁSQUEZ, H. M.; HERNÁNDEZCRUZ, J.; GASCA-ÁLVAREZ, H. J. 2020. Description of teratologies in two species of the genus Phyllophaga (Coleoptera: Scarabaeidae: Melolonthinae). Revista Colombiana de Entomología 46 (1): e8538. https://doi. org/10.25100/socolen.v46i1.8538

Received: 16-Feb-2019

Accepted: 1-Aug-2019

Published: 9-Jul-2020

Revista Colombiana de Entomología

ISSN (Print): 0120-0488

ISSN (On line): 2665-4385

http://revistacolombianaentomologia.univalle.edu.co/

Open access

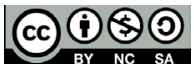

BY-NC-SA 4.0

Publishers:

Sociedad Colombiana de Entomología SOCOLEN (Bogotá, D. C., Colombia) http://www.socolen.org.co Universidad del Valle (Cali, Colombia) http://www.univalle.edu.co/

(C) 2020 Sociedad Colombiana de Entomología - SOCOLEN y Universidad del Valle - Univalle
Abstract: The aim of this work is to describe and illustrate new teratological cases in species of the genus Phyllophaga. A total of 830 specimens collected in 2013 and 2017 in Sierra Sur region of the state of Oaxaca, Mexico were reviewed. Two cases of morphological anomalies were found. The first case is a clypeal malformation in Phyllophaga dasypoda, and the second case is a bifurcated right antenna with double antennal club in Phyllophaga misteca.

Keywords: Anomalies, malformations, may beetles, schistomely, symphysocery.

Resumen: El objetivo de este trabajo es describir e ilustrar nuevos casos teratológicos en especies del género Phyllophaga. Se revisaron 830 especímenes recolectados en 2013 y 2017, en la región Sierra Sur del estado de Oaxaca, México. Se encontraron dos casos de anomalías morfológicas. El primero es una malformación del clípeo en Phyllophaga dasypoda, y el segundo es una bifurcación de la antena derecha con doble maza antenal en Phyllophaga misteca.

Palabras clave: Anomalías, malformaciones, escarabajos de mayo, esquistomelia, sinfisoceria.

\section{Introduction}

Teratology is defined as the study of structural anomalies, monstrosities and malformations (Torre-Bueno 1985). Teratologies in insects are usually not reported, since they are not considered to have a taxonomic value because they are specimens that present atypical morphological characters to the taxon to which they belong (Caruso and Savini 2012). However, it is very important that entomologists and especially taxonomists consider teratological cases, as they can offer valuable information on the influence of endogenous and exogenous factors in the process of embryonic development (Savini and Furth 2004; Caruso and Savini 2012). Teratologies can be grouped into four major categories: general, corporal, appendicular and wing-elytra anomalies. These can be divided into several groups according to their typology (Balazuc 1948; Ortuño 2000). The majority of anomalies described in insects are related to the development and structure of the appendages, the most common of being symphysoceries (fusion of segments), schistomelies (branch of appendages) and dystrophies (reduction of the appendix size) (Cockayne 1937; Ortuño and Peláez 2004).

Of the reports on teratomorphous insects, the order Coleoptera has the highest number of described cases (Savini and Furth 2004; Márquez and Sierra-Martínez 2008). The most frequent families are Carabidae, Cerambycidae, Staphylinidae, Chrysomelidae (Savini and Furth 2004; Ortuño and Ramos-Abuín 2008), and recently Scarabaeidae (Gasca-Álvarez et al. 2017), Lucanidae and Geotrupidae (Kizub and Leshchenko 2019). Regarding the genus Phyllophaga Harris, 1827, only malformations of the antenna and legs have been described in P. (Cnemarachis) bruneri Chapin, 1932 and P. (Phyllophaga) glaberrima (Blanchard, 1851), respectively (Dodge 1965; Ferreira 2011). 
New cases of malformations in two species of Phyllophaga are described here. This work continues the study of teratologies in the superfamily Scarabaeoidea (see Gasca-Álvarez et al. 2017 and Gasca-Álvarez et al. 2018).

\section{Materials and methods}

A total of 830 specimens of the genus Phyllophaga were reviewed; these specimens were collected under street lighting in two collection events: the first event was held in 2013 in the locality of Santa Cruz Itundujia, and the second event in 2017 in the locality of Santa Ana Tututepec. Both in Sierra Sur region of the state of Oaxaca, Mexico. Additional information of the localities is included in the labels of the analyzed specimens.

For the taxonomic determination of the specimens, the key of Morón (1986) was used, the original descriptions of Bates (1888) were reviewed and the male genitalia were compared with the photographs and illustrations presented in Morón (1986), Cano and Morón (1999), and Hernández-Cruz et al. (2014). Also, the determination was corroborated by Dr. Miguel Ángel Morón (R.I.P.) in the Institute of Ecology (INECOL Xalapa, Veracruz). For the identification of the type of anomalies, as well as the terminology and classification we follow the proposed of Balazuc (1948), Ortuño and Hernández (1993), Ortuño and Vique (2007), Asiain and Márquez (2009) and Ceccolini and Paggetti (2015). Images were taken with a Canon EOS Rebel T6 camera adapted to a stereo-microscope Zeiss model Stemi 508. The examined specimens are deposited in the insect collection of the Centro Interdisciplinario de Investigación para el Desarrollo Integral Regional (CIIDIR), Unidad Oaxaca, Instituto Politécnico Nacional (IPN).

\section{Results}

Of the 830 specimens examined, 300 individuals belong to $P$. dasypoda and 530 to $P$. misteca. Only one specimen of each species showed abnormalities. The two teratological cases are described below:

\section{Case 1:}

Material examined. Phyllophaga (Phyllophaga) dasypoda (Bates, 1888) (Fig. 1A). 1§. México, Oaxaca, Juquila, Santa Ana Tututepec. 16 $10^{\circ} 53^{\prime} \mathrm{N} 97^{\circ} 31^{\prime} 50^{\prime} \mathrm{O}, 445 \mathrm{~m}$. Manual capture, 2-June-2017. Cruz Ruíz, E. [IPN-CICO]

Type of anomaly. Clypeal hypertrophy.

Description. The head presents a malformed clypeus due to the presence of a prominent projection. Unlike a normal clypeus (Fig. 1B), this has a globose and parabolic aspect, exaggeratedly inflated dorsally, with greater elevation in the center and decreasing towards the edges, which are flattened (Fig. 1C).

\section{Case 2:}

Material examined. Phyllophaga (Phyllophaga) misteca (Bates, 1888) (Fig. 2A). 1 ${ }^{\lambda}$. México, Oaxaca, Santa Cruz Itundujia, Unión de Galeana. 1652'27’N 97³9'41'O, 2.350 m. Manual capture, 27-May-2013. Girón Pablo, H. [IPN$\mathrm{CICO}]$

Type of anomaly. Antenna with unilateral heterodynamic binary schistomely and symphysocery type $3-4,3 b-4 b$ and $5 b-6 b-7 b$.

Description. Bifurcated right antenna. It is clearly observed that from the third antennomere it branches into two antennae
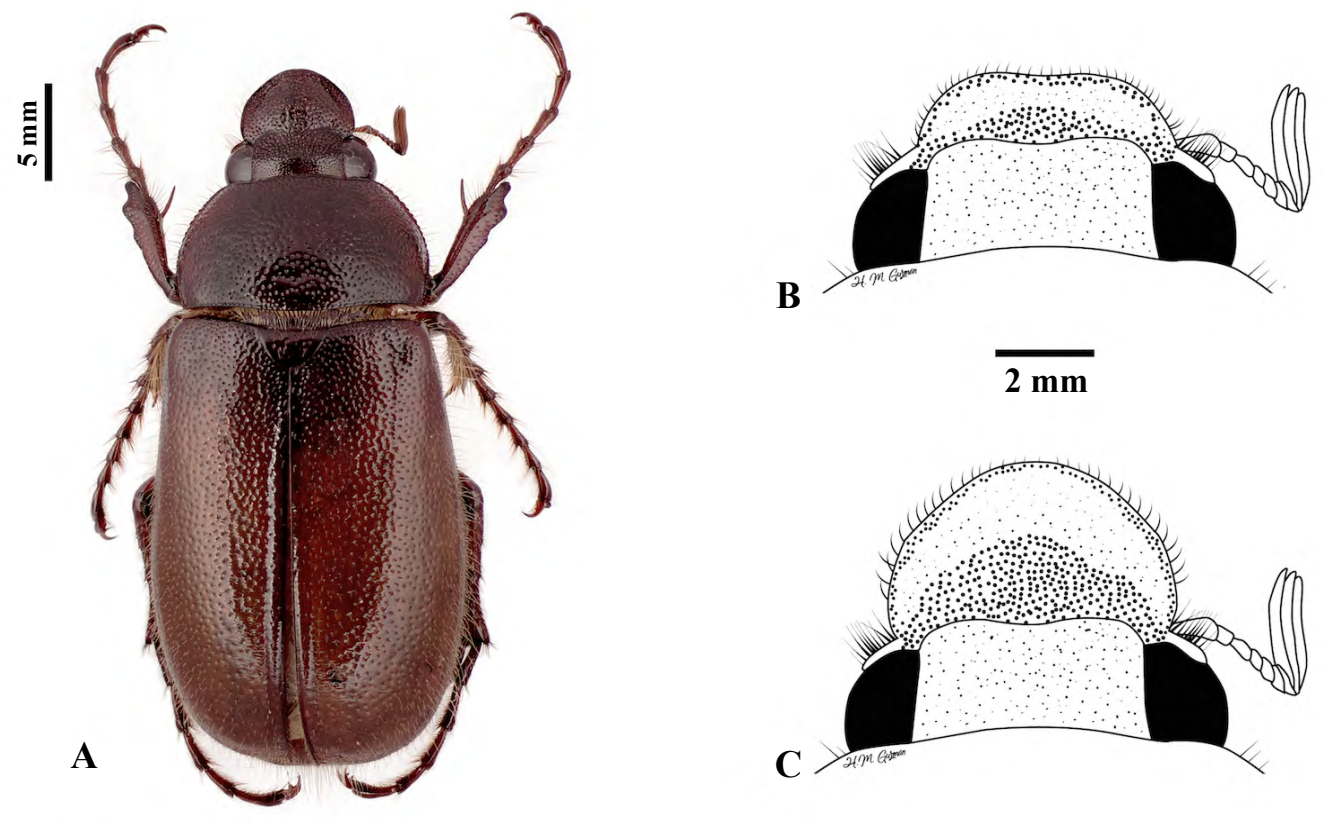

Figure 1. A. Dorsal aspect of the teratological specimen of $P$. dasypoda (ð). B. Normal clypeus. C. Clypeus with malformation. 

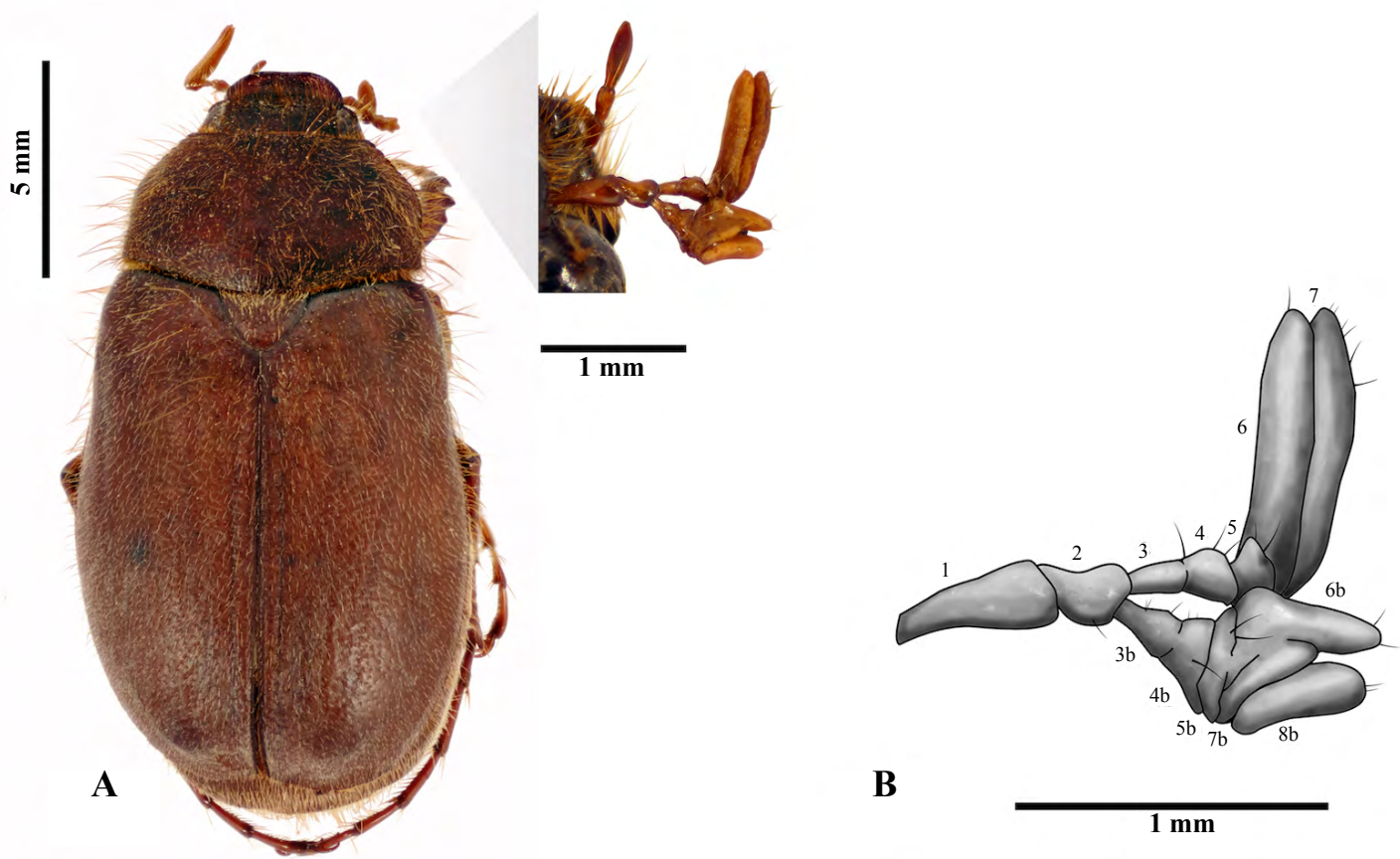

Figure 2. A. Dorsal aspect of the teratological specimen of P. misteca $\left({ }^{\Uparrow}\right)$. B. Bifurcated antenna.

(Fig. 2B). The antennomeres 3, 4, 5, 6 and 7 form the main antenna, in which the antennal club is constituted by only two antennomeres ( 6 and 7). Antennomeres 3 and 4 are fused. The second antenna is formed by the antennomeres $3 b, 4 b, 5 b$, $6 \mathrm{~b}, 7 \mathrm{~b}$ and $8 \mathrm{~b}$. The antennomeres $6 \mathrm{~b}, 7 \mathrm{~b}$ and $8 \mathrm{~b}$ constitute the secondary antennal club. All the antennomeres of this branch are partially or totally fused except for $8 \mathrm{~b}$.

\section{Discussion}

The anomalies in beetles' antennae are very frequent. Generally, the flagellum undergoes a multisegmentation process during the pupation, which unleashes errors in the arthrogenesis process in the imago antenna (Ortuño and Vique 2007). As a result, schistomelies (division of the antenna into two or more branches) and symphysoceries (partial or total antennomeres fusion) occur. These malformations have been widely studied in several Coleoptera groups (Dodge 1965; Baraud 1977; Savini and Furth 2004; Márquez and SierraMartínez 2008; Ortuño and Ramos-Abuín 2008; Ferreira 2011; Gasca-Álvarez et al. 2017).

The fusion of antennomeres usually produces an aberrant and dystrophic antennal piece. Antennomeres that have not been affected, occasionally are also dystrophic (Ortuño and Marcos 2003; Ortuño and Peláez 2004). The most frequent fusions occur from the 5th antennomere, with mergers that involve the 4th and 5th and very rare fusions that affect the 3rd and 4th (Balazuc 1948), as in the case of Phyllophaga misteca.

The schistomelies can be partial or total divisions of the antenna in two or more growth axes. It is possible to find schistomelies of second and third degree, multiple and even combined schistomelies (Balazuc 1948). Due to its complexity, associated symphysoceries are usually presented, such as the case described in this paper.

According to Balazuc (1948), two theories could explain the origin of the schistomelies. The division of muscle fibers and the production of an exaggerated plastic force that generates inequality in the distribution of fibers, cause an excess at the apex of the appendages and leads to division. The second theory is related to the multiple formation of imaginal discs during the last larval stage, which would give rise to partial organs. However, the genetic basis of this type of malformation is still unknown.

The case of the clypeus with excessive growth and development, is a very rare anomaly, and so far, there are no reports of this type of malformations in Scarabaeidae or in some other Coleoptera group in the literature. So, this could be the first documented case of this type of anomaly. The only close case is the unilateral deformation of the clypeus in Lucanus cervus (Linnaeus, 1758) reported by Frivaldszky (1889).

Perhaps the origin of this anomaly is due to the contact with chemical substances (exogenous factors) that were in the environment during the embryonic development (Balazuc 1948; Ghannem et al. 2015). This could possibly be due to the use of agrochemicals in crops and other types of agroecosystems (Ortuño 2000). Although it is very important to take into consideration the etiology, sometimes it is not possible to determine the exact causes that originated these malformations (Ghannem et al. 2015; Kizub and Leshchenko 2019).

\section{Conclusions}

So far, only two cases of teratology have been reported in species of the genus Phyllophaga (P. bruneri and P. glaberrima), the cases described here represent two new cases of teratologies in two species more than the previous ones. Dr. Morón (pers. comm.) frequently observed malformations in the antennae of P. (Phytalus) pentaphylla (Bates, 1888). However, we do not know the frequency of these anomalies because he did not publish this data. 
It is important to document teratological cases, since they can show how the exogenous and endogenous factors influence in the processes of embryonic development. In addition, it is necessary to continue studying teratologies in order to know their origin, record the frequency with which they occur, and discover how these anomalies affect the activity of teratomorphic individuals.

\section{Acknowledgments}

We dedicate this contribution to Miguel Ángel Morón (R.I.P.), mainly for his dedication to the study of the genus Phyllophaga in Mexico and America. We thank Timothy F. James O'Hara for the English review. We are grateful with Elfega Cruz Ruíz and Herminia Girón Pablo for collecting the specimens analyzed in this study. First author thanks CONACyT and IPN for the master's scholarship [454318]. We also thank two anonymous reviewers for their valuable comments that helped enrich this manuscript.

\section{Literature cited}

ASIAIN, J.; MÁRQUEZ, J. 2009. New teratological examples in Neotropical Staphylinidae (Insecta: Coleoptera), with a compilation of previous teratological records. Revista Mexicana de Biodiversidad (80): 129-139.

BALAZUC, J. 1948. La Tératologie des Coléoptères, et expériences de transplantation chez Tenebrio molitor L. Mémoires du Muséum National d'Histoire Naturelle (Nouvelle série) (Paris) 25: 1-293.

BARAUD, J. 1977. Aberrations antennaires et taxinomie chez les Melolonthidae. Nouvelle Revue d'Entomologie 3 (7): 315-320.

BATES, H. W. 1888. Insecta. Coleoptera. Pectinicornia and Lamellicornia. pp. 193-209. In: Godman, F. D.; Salvin, O. (Eds.). Biologia Centrali-Americana. Volume 2. Part 2. London. 432 p.

CANO, E. B.; MORÓN, M. A. 1999. Phyllophaga (Coleoptera: Scarabaeidae: Melolonthinae) de Guatemala: sistemática, diversidad, biología y biogeografía. FONACYT. Universidad del Valle de Guatemala. Guatemala. 100 p.

CARUSO, D.; SAVINI, V. 2012. Tres casos teratológicos de Gioia georgia Bechyné, 1955 (Coleoptera: Chrysomelidae) en Choroní, Estado Aragua, Venezuela. Entomotropica 27 (2): 89-91.

CECCOLINI, F.; PAGGETTI, E. 2015. Nota sobre las teratologías antenales en cerambicoideos, con descripción de nuevos casos (Coleoptera: Cerambycoidea). Boletín de la Sociedad Entomológica Aragonesa (57): 383-389.

COCKAYNE, E. A. 1937. Insect teratology. Reduplication of legs in Coleoptera, Diptera and Hymenoptera. Transactions of the Royal Entomological Society of London 86: 191-202. https:// doi.org/10.1111/j.1365-2311.1937.tb00424.x

DODGE, H. R. 1965. Three examples of insect teratology. Proceedings of the Entomological Society of Washington 67 (2): 120.

FERREIRA, R. N. 2011. Three anomalies of Coleoptera (Carabidae, Staphylinidae, and Scarabaeidae) from Connecticut. Insecta Mundi 169: 1-3.

FRIVALDSZKY, J. 1889. Difformitates et monstrositates Coleopterorum Muszei nationalis Hungarici. Természetrajzi Füzetek 12 (2/3): 72-79.

GASCA-ÁlVAREZ, H. J.; DELOYA, C.; REYES-CASTILlO, P. 2017. Teratological cases in five species of Cotinis Burmeister (Coleoptera: Scarabaeidae: Cetoniinae: Gymnetini), with a compilation of teratologies in Scarabaeoidea. The Coleopterists Bulletin 71 (2): 329-338. https://doi.org/10.1649/0010065X-71.2.329
GASCA-ÁlvareZ, H. J.; SKElley, P.; DElOYA, C. 2018. A remarkable teratological specimen of Trichiotinus rufobrunneus (Casey) (Coleoptera: Scarabaeidae: Cetoniinae: Trichiini). Insecta Mundi 0680: 1-5.

GHANNEM, S.; ZRELLI, S.; BOUMAIZA, M. 2015. New teratological record in Carabidae (Insecta: Coleoptera) from Tunisia. Arquivos Entomolóxicos 14: 127-129.

HERNÁNDEZ-CRUZ, J.; MORÓN, M. A.; RUÍZ-VEGA, J.; SÁNCHEZ-GARCÍA， J. A.; MARTÍNEZ-MARTÍNEZ, L.; PÉREZ-PACHECO, R. 2014. Bionomía de las especies de Phyllophaga (Coleoptera: Melolonthidae) en Santa Cruz Xoxocotlán, Oaxaca, México. Acta Zoológica Mexicana (n.s.) 30 (1): 144-160. https://doi.org/10.21829/azm.2014.301135

KIZUB, I. V.; LESHCHENKO, M. V. 2019. New cases of teratology in Lucanidae and Geotrupidae (Coleoptera: Scarabaeoidea) from the Palearctic region. Munis Entomology and Zoology Journal 14 (1): 108-116.

MÁRQUEZ, J.; SIERRA-MARTÍNEZ, S. 2008. Teratología y nuevo registro de Chrysina adelaida (Hope, 1840) (Coleoptera: Scarabaeidae: Rutelinae). Dugesiana 15 (1): 39-40.

MORÓN, M. A. 1986. El género Phyllophaga en México. Morfología, sistemática y distribución supraespecífica (Insecta: Coleoptera). Publicación No. 20. Instituto de Ecología, D. F., México. $341 \mathrm{p}$.

ORTUÑO, V. M. 2000. Malformaciones en los coleópteros. Investigación y Ciencia 290 (11): 40-41.

ORTUÑO, V. M.; HERNÁNDEZ, J. M. 1993. Diversos casos teratológicos en Coleoptera. Boletín de la Real Sociedad Española de Historia Natural 89 (1-4): 163-179.

ORTUÑO, V. M.; MARCOS, J. Mª 2003. Los Caraboidea (Insecta: Coleoptera) de la Comunidad Autónoma del País Vasco. Tomo I. Biodiversidad, 2. Servicio de Publicaciones del Gobierno Vasco. $1^{\mathrm{a}}$ ed. Vitoria-Gasteiz. 574 p.

ORTUÑO, V. M.; PELÁEZ, L. 2004. Nuevos e interesantes casos de carábidos teratomorfos (Coleoptera, Adephaga, Carabidae). Bulletin de la Société Entomologique de France 109 (3): 251256.

ORTUÑO, V. M.; RAMOS-ABUÍN, J. A. 2008. Reflexiones sobre la teratología y descripción de cuatro teratosis apendiculares en Coleoptera. Boletín de la Sociedad Entomológica Aragonesa (43): 435-439.

ORTUÑO, V. M.; VIQUE, I. M. 2007. Descripción de algunos carábidos teratomorfos (Coleoptera: Adephaga: Carabidae). Boletín de la Sociedad Entomológica Aragonesa (40): 463-469.

SAVINI, V.; FURTH, D. 2004. Teratología en Coleoptera: un caso en Gioia bicolor (Blake, 1969) (Chrysomelidae, Alticinae) de Jamaica. Entomotropica 19 (3): 165-167.

TORRE-BUENO, J. R. DE LA. 1985. A glossary of entomology and supplement A. New York Entomological Society. 336 p.

\section{Origin and funding}

This work was carried out by the first author as part of the activities during his Master of Science studies. It was financed by Instituto Politécnico Nacional (IPN) and Consejo Nacional de Ciencia y Tecnología (CONACyT), Mexico.

\section{Author contribution}

Héctor Miguel Guzmán-Vásquez: description of teratologies, photography, taxonomic identification of specimens, writing, review and correction of the manuscript.

Julián Hernández-Cruz: taxonomic identification of specimens and revision of the manuscript.

Héctor Jaime Gasca-Álvarez: writing and critical revision of the manuscript. 